\title{
CHEMICAL AND SENSORIAL CHARACTERISTICS OF FRUIT SPIRITS PRODUCED FROM DIFFERENT BLACK CURRANT (RIBES NIGRUM L.) AND RED CURRANT (RIBES RUBRUM L.) CULTIVARS
}

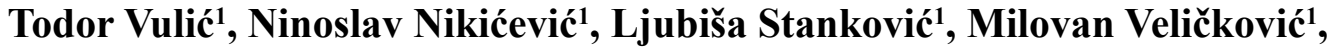 \\ Marina Todosijević ${ }^{2}$, Branko Popović ${ }^{3}$, Ivan Urošević 1 , Miroslava Stanković ${ }^{4}$, \\ Isidora Beraha ${ }^{5}$, Vele Tešević2*
}

\author{
${ }^{1}$ Faculty of Agriculture, University of Belgrade, Nemanjina 6, 11080 Zemun, Serbia \\ ${ }^{2}$ Faculty of Chemistry, University of Belgrade, Studentski trg 16, 11000 Belgrade, Serbia \\ ${ }^{3}$ Fruit Research Institute, Kralja Petra I br.9, 32000 Čačak, Serbia \\ ${ }^{4}$ Institute for Chemistry, Technology and Metallurgy, University of Belgrade, \\ Njegoševa 12, 11000 Belgrade, Serbia \\ ${ }^{5}$ Institute of Economic Sciences, Zmaj Jovina 12, 11000 Belgrade, Serbia
}

\author{
todor@agrif.bg.ac.rs, ninoslavyug@yahoo.com, ljubisas@agrif.bg.ac.rs, \\ mvelicko@agrif.bg.ac.rs, marinab@chem.bg.ac.rs, popovicb@tfc.kg.ac.rs, \\ office@tok.co.rs, mstankovic@vin.bg.ac.rs, isidora.beraha@ien.bg.ac.rs, vtesevic@chem.bg.ac.rs
}

\begin{abstract}
The chemical characteristics of fruit spirits produced from three black currant cultivars (Malling Juel, Ometa and Ben Sarek) and two red currant cultivars (Rondom and Versailles) grown in Serbia were examined using gas chromatography. In addition, a sensory evaluation of the spirit samples was performed using the Buxbaum model of positive rating. Fruit spirits produced from black currant cultivars displayed the highest contents of methanol (267.2-595.0 g/hl A.A.) and amyl alcohols (74.2-204.8 g/hl A.A.). Total sensory scores of currant brandies ranged between 17.60 and 18.40, while currant brandy produced from the Ben Sarek black currant cultivar received the highest score (18.40). All tested samples of currant brandies fulfilled EU requirements as regards their content of methanol and other components such as acetaldehyde, ethyl acetate, and high alcohols. The currant distillates were compared with other commercial spirits, including plum and grape brandies.
\end{abstract}

Key words: black currant; red currant; cultivar; fruit spirit; gas chromatography

\section{ХЕМИСКИ И СЕНЗОРНИ КАРАКТЕРИСТИКИ НА ОВОШНИ АЛКОХОЛНИ ПИЈАЛАЦИ ДОБИЕНИ ОД СОРТИ НА ЦРНА (RIBES NIGRUM L.) И ЦРВЕНА РИБИЗЛА (RIBES RUBRUM L.)}

Со гасна хроматографија беа испитувани хемиските карактеристики на овошни алкохолни пијалаци добиени од три сорти црна рибизла одгледани во Србија (Malling Juel, Ometa, и Ben Sarek) и две сорти црвена рибизла (Rondom и Versailles). Покрај тоа, направена е и процена на сензорни особини со Баксбаумов (Buxbaum) модел на позитивно рангирање. Овошните алкохолни пијалаци добиени од црни рибизли содржат најголема количина метанол $(267,2-595,0 \mathrm{~g} / \mathrm{hl}$ А. А.) и амилалкохоли (74,2-204,8 g/hl A. А). Вкупниот сетилен коефициент на ракијата од рибизла изнесува помеѓу 17,60 and 18,40, додека ракијата добиена од сортата на црна рибизла Ben Sarek има највисок 
коефициент $(18,40)$. Сите тестирани примероци на ракии од рибизли ги исполнуваат барањата на EU во однос на содржината на метанол и други компоненти како што се ацеталдехид, етилацетат и виши алкохоли. Дестилатите од рибизла се споредени со други комерцијални алкохолни пијалаци од слива и грозје.

Клучни зборови: црна рибизла; црвена рибизла; сорти; овошни алкохолни пијалаци; гасна хроматографија

\section{INTRODUCTION}

The genus Ribes contains about 150 species, notably the red and white currants ( $R$. rubrum L. and $R$. sativum Syme) and the black currant $(R$. nigrum L.). The genus Ribes is native to the high latitudes of the northern hemisphere. Europe, Asia, and North America all have native species. By far, the greatest part of commercial production is concentrated in Europe and the former USSR, and most cultivars have been derived from species native to these areas. Currant cultivation has been practiced at least since the 1500s in Europe and the late 1700s in North America when the first European colonists arrived [1]. Ribes fruit are marketed almost entirely as frozen, juice, jam, or jelly. In France, a fruit spirit is made from the black currant cultivar "Noir de Bourgogne". Black currants are also used in many desserts, such as pies, while red currants are mostly made into jelly/jam. Fresh fruits are usually processed by consumers into various dessert items. Currant fruits are a good source of vitamins, antioxidants, non-volatile organic acids, and phenolic acids that contribute to the quality of taste and aroma [2]. In addition, these fruits have been reported to have natural therapeutic qualities [3].

The aroma profile of black and red currant shares similarities with that of other berry fruits. Over 150 volatile compounds have been reported from currant berries, of which the major groups are monoterpenes, sesquiterpenes, esters, and alcohols [4]. The most important volatile compounds for the black currant berry aroma include esters such as 2-methylbutyl acetate, methyl butanoate, ethyl butanoate, and ethyl hexanoate with fruity and sweet notes, nonanal, $\beta$-damascenone, and several monoterpenes $(\alpha$-pinene, 1,8 -cineole, linalool, terpinen-4-ol, and $\alpha$-terpineol), as well as aliphatic ketones (e.g. 1-octen-3-one) and sulfur compounds such as 4-methoxy-2-methyl-butanethiol. 4-Methoxy-2-methylbutanethiol has a characteristic "catty note" and is very important to black currant flavor [5]. Currant berries contain a wide range of flavonoids and other phenolic compounds that possess antioxidant activity. Most of these compounds remain present in berry and fruit products, such as juices and wine. Anthocyanins, as well as other phenolics, can act as antioxidants by donating hydrogen to highly reactive radicals, thereby preventing further radical formation [6]. Wines made from mixtures of black currants and crowberries or bilberries are effective in the inhibition of methyl linoleate peroxidation [7].

Berries are not as widely used for distillation as stone fruit or pome fruit. Cultivated berries possess a relatively low sugar content of 4-8 \% (exceptions: grape and rosehip) compared to wild berries [8], which results in a relatively low yield of distillate and subsequently makes the raw material cost quite high. Berries are more widely used for the production of liqueurs due to their significant amount of phenolic compounds and high antioxidant activity [9]. Raspberries, blackberries, and currants are the most widely used raw materials for distillate production. Cranberries and elderberries are rich in tannins and are partially low in nitrogen; therefore, supplementation using fermentation aids should be used to avoid fermentation hold-ups. Juniper berries are commonly used dried and their sugar content is around an average of $20 \%$ [8]. Black and red currants (cultivars Ribes nigrum L. and Ribes rubrum L.) are ubiquitously grown in Serbia, but on relatively 
small areas with production far behind that of strawberry, raspberry, and blackberry; this does not meet the needs of the country. Today, there is a worldwide tendency towards producing so-called delicatessen fruit brandies, such as quince, raspberry, blackberry, cornel berry, currant, and blueberry brandy. If produced using proper technological procedures, they give great organoleptic pleasure to the consumer.

In recent years, intensive studies have been carried out regarding the sensory activity of the individual components of alcoholic beverage odors, and the dependence between the odor and the chemical composition of the volatile fraction of these products [10]. Gas chromatography (GC) is a powerful tool in the analysis of alcoholic beverage products. Minimal sample preparation, in general, is required since the samples are in the liquid state in an alcohol or alcohol/water matrix. The flavor compounds tend to be volatile in nature, which fulfills one of the main requirements of GC. General detectors such as a flame ionization detector (FID), or more information-rich detectors, such as a mass selective detector (MS) can be used. The primary objective of this paper is to present the chemical and sensory analyses of distillates produced from different currant cultivars (Malling Juel, Omete, Rondom, Ben Sarek and Versailles). Along with the abovementioned analyses, the volatile compounds in the distillates were compared to those in other commercially available spirits.

\section{MATERIALS AND METHODS}

\subsection{Chemicals}

Reference standards (chromatographic grade) of methanol, 1-propanol, 2-methyl-propanol, 1-butanol, 2-methyl-1-butanol, 3-methyl-1-butanol, hexanol, 4-methyl-1-pentanol, ethyl acetate, and acetaldehyde were purchased from Merck (Darmstadt, Germany). The purity of all chemicals was above $98 \%$.

\subsection{Plant material properties of currant cultivars}

Currently, Serbia's annual production of currants is between 100 to 150 tons. The majority of this produce is processed into fruit juices or used for making mixed frozen fruit packs, while approximately $40 \%$ is sold fresh at markets and/or consumed in growers' households. Among the currant cultivars, those presented below have the dominant share.

Cultivar Ben Sarek was developed in Scotland (Scottish Crop Research Institute, Invergowrie, Dundee). The parents are Goliath $\times$ Ojebyn. Ripening season: mid-early, in the second half of June. It forms a small compact shrub. The shoots are moderately vigorous and the plant rarely exceeds one meter in height.

Cultivar Malling Juel was developed in England at the Institute of East Malling. The ripening season: mid-late, late June-early July. It forms a very dense bush with shoots reaching a length of over 1.5 meters, but produces few new shoots. It is a native cultivar and produces its highest yield on three-year old shoots.

Cultivar Omete was developed in Switzerland. Ripening season: late, second half of July. It forms a moderately dense and compact bush. The taste of the fruit is excellent and suitable for fresh consumption.

Cultivar Rondom is a Dutch cultivar. Ripening season: mid-early to mid-late, late June. It is a heavy cropper with long strings. The berries are of a uniform size.

Cultivar Versailles is an old French cultivar. Ripening season: mid-early, in the third week of June. It is a regular and heavy cropper. The bush is moderately vigorous with erect branches. It forms medium-large strings with numerous, medium sized berries. The taste of the fruit is slightly sour and aromatic. It is suitable for all kinds of treatment (use).

The fruits of these five currant cultivars (Malling Juel, Ometa, Rondom, Ben Sarek and Versailles) were harvested in 2008 from the experimental orchard at Radmilovac, property of 
the Faculty of Agriculture, University of Belgrade.

Currants were grown on an experimental plantation established using the hedgerow system with a $2.8 \times 1.2 \mathrm{~m}$ planting distance. The fruits were sampled at the optimal ripening stage ranging from June 17 (Ben Sarek) to July 3 (Ometa). High yielding black and red currant cultivars produced $1.82 \mathrm{~kg} / \mathrm{bush}$ (Ben Sarek), $2.25 \mathrm{~kg} / \mathrm{bush}$ (Malling Juel) and $2.94 \mathrm{~kg} / \mathrm{bush}$ (Rondom). The low yielding cultivars Ometa (1.12 kg/bush) and Versailles (1.37 kg/bush), whose berries contain abundant quantities of soluble solids (18.23\% and $13.80 \%$ ), were also included in this experiment.

\subsection{Distillation process}

The fruit was crushed by grinding before fermentation and transferred into 201 plastic vessels. The fermentation procedure of disintegrated fruits was carried out at room temperature $\left(20^{\circ} \mathrm{C}\right)$ over a two-week period. Initially, manual homogenization was done for 3-4 days, while the dynamics of dry matter content and fermentation temperature reduction were monitored daily using a manual refractometer and thermometer. In all experimental variants, the fermentation procedure was carried out with spontaneous (autochthonous) microflora under identical conditions over a period of 15 days.

The distillation of fermented currant fruits (so-called Distillation I) was carried out in a simple laboratory copper pot still with a capacity of 20 liters In the first instance, the brandy fraction was not separated in order to preserve the aromatic complex, while the middle fraction, i.e. the production of the major distillate, lasted until the ethanol concentration dropped to a value of 15 to $19 \%(V / V)$ on average in the mass.

The redistillation of raw soft currant brandies (so-called Distillation II) was carried out using the same type of apparatus but with a smaller volume (5 liters). At first, the brandy fraction (the so-called head) was separated, in an amount of $1.2 \%$, from the rest of the initial raw soft brandy to eliminate a certain excess of acetaldehyde and ethyl acetate. The major distillate (the distillation head) was separated from the tail when the ethanol concentration amounted, on average, to $60-62 \%(V / V)$ in the mass. The tail fraction was collected at an average ethanol concentration of $25 \%(V / V)$ in the mass.

All experiments were performed in triplicate, and parameters such as ethanol yields and ethanol content were determined after the first distillation and the procedure of redistillation. The major volatile compounds were determined only in samples obtained after the second step of distillation (redistillation).

\subsection{Analysis of chemical parameters of currant fresh fruit pulp}

The sugar content, the dry matter, and the total acidity of the fresh fruit pulp were measured as follows: the sugar content and the dry matter using a Carl Zeiss Jena Hand refractometer Model 711849 (Germany), and the acidity by volumetric titration with $0.1 \mathrm{M} \mathrm{NaOH}$ using phenolphthalein as an indicator. The acidity was expressed in terms of malic acid [11].

\subsection{GC analysis of volatile compounds}

The major volatile components were analyzed on the basis of the European Community Reference Methods for the analysis of spirits using gas chromatography (GC) with a flame-ionization detector (FID) [12]. The main components, including methanol, acetaldehyde, 1-propanol, ethyl acetate, 2-methyl-1-propanol, 1-butanol, amyl alcohols, and 1-hexanol, were identified by comparing their retention times with those of authentic compounds. For quantitative evaluation the internal standard method was applied, with a known amount of 4-methyl1-pentanol as the internal standard (IS). As such, 
an ethanol solution containing $5 \mathrm{~g} / 1$ 4-methyl1-pentanol was added to $10 \mathrm{ml}$ of each sample. The concentration of each volatile was determined with respect to the internal standard from the relative response factors (RRF), which were obtained during calibration under the same chromatographic conditions as those of the sample analysis [13].

The GC analysis was carried out on a HP 5890 gas chromatograph equipped with a flame ionization detector (FID) and a split/splitless injector. A capillary column $(30 \mathrm{~m} \times 0.25 \mathrm{~mm}$, $0.52 \mu \mathrm{m}$ film thickness i.d.) coated with a HP-5 (5\% diphenyl and 95\% dimethylpolysiloxane) was used. The column oven temperature was programmed from $50^{\circ} \mathrm{C}$ to $285^{\circ} \mathrm{C}$ at a rate of $4.3^{\circ} \mathrm{C} / \mathrm{min}$, and the injection port and detector temperatures were kept at $250^{\circ} \mathrm{C}$. Hydrogen was used as the carrier gas at a flow rate of 1.6 $\mathrm{ml} / \mathrm{min}$ with a split ratio of 60:1. Sample volume was $1 \mu \mathrm{l}$ injected directly into the GC system.

\subsection{Sensory analysis}

The sensory analysis of the obtained samples of strong currant brandies was performed by a five-member expert panel consisting of three university professors and two engineers of food technology (BSc). All the panellists are welltrained and have extensive practical experience in the field. The evaluation was conducted anonymously using the modified Buxbaum method, which is the worldwide accepted method for sen- sory evaluation of strong alcoholic drinks. The samples were coded [14].

\subsection{Statistical analysis}

The statistical analysis was performed using Origin software package version 7.0. The statistical significance of the difference between the data pairs for alcohol content was evaluated by analysis of variance (One-way ANOVA) followed by the Tukey test. Statistical differences were considered significant at $\mathrm{p}<0.05$.

\section{RESULTS AND DISCUSSION}

Measuring the sugar content in the fresh fruit pulp of the examined currant cultivars (Table 1) indicated that the highest average sugar content $(72 \mathrm{~g} / \mathrm{kg})$ was found in the cv. Malling Juel, while the lowest content of sugar (45 g/ $\mathrm{kg}$ ) was found in the cv. Versailles. Comparing the varieties Random, Versailles and Ometa, no significant differences were observed in the content of sugars. Considering the total acids, the highest content was measured for the cv. Ometa $(24 \mathrm{~g} / \mathrm{kg})$, while the lowest content was in the cv. Ben Sarek $(14 \mathrm{~g} / \mathrm{kg})$. Comparing the varieties Random, Versailles and Malling Juel, no significant differences were observed in the content of total acids (19-21 g/ $/ \mathrm{kg}$ ). These results point to the fact that the chemical fruit composition did not vary much among the analyzed cultivars.

Table 1

Chemical parameters of currant fresh fruit pulp

\begin{tabular}{lcccccccccc}
\hline \hline & \multicolumn{2}{c}{ Rondom } & \multicolumn{2}{c}{ Versailles } & \multicolumn{2}{c}{ Ben Sarek } & \multicolumn{2}{c}{ Malling Juel } & \multicolumn{2}{c}{ Ometa } \\
\cline { 2 - 11 } & Mean+SE & SD & Mean+SE & SD & Mean+SE & SD & Mean+SE & SD & Mean+SE & SD \\
\hline $\begin{array}{l}\text { Sugars g/kg } \\
\begin{array}{l}\text { Dry matter } \\
\text { g/kg }\end{array}\end{array}$ & $47 \pm 0.02$ & 0.02 & $45 \pm 0.01$ & 0.04 & $55 \pm 0.02$ & 0.03 & $72 \pm 0.03$ & 0.05 & $46 \pm 0.03$ & 0.04 \\
$\begin{array}{l}\text { Total acids } \\
\mathrm{g} / \mathrm{kg}\end{array}$ & $95 \pm 0.03$ & 0.05 & $91 \pm 0.04$ & 0.10 & $110 \pm 0.3$ & 0.5 & $141 \pm 0.1$ & 0.1 & $91 \pm 0.1$ & 0.1 \\
\hline \hline
\end{tabular}

Mean - arithmetic mean; $\mathrm{SE}(\mathrm{yEr} \pm$ ) - Standard error; $\mathrm{SD}(\mathrm{yEr} \pm$ ) - Standard deviation 
Organic acids, esters, and higher alcohols formed the main body of the congener compounds (all compounds other than ethanol and water) in the distilled spirits. Some other compounds were also present in the distillate such as esters, aldehydes, ketones, volatile acids, and terpenes.

\subsection{Ethanol}

The results for the determination of alcoholic strength and volatile composition are outlined in Table 2. The alcoholic strength of the samples ranged from $42.7 \%$ to $45.4 \%(V / V)$. The concentrations of the volatiles are expressed as grams/hectoliter absolute alcohol (g/ hl A.A.) according to European Regulation EC 2870/2008 [12]. A characteristic chromatogram observed for currant spirits samples is presented in Fig. 1. The main volatile compounds detected in the currant spirits samples by the direct injection method were acetaldehyde, ethyl acetate, methanol, 1-propanol, 2-methyl- 1-propanol, 1-butanol, and amyl alcohols, by the order of retention times. The major volatile compounds identified in the five spirits are presented in Table 2.

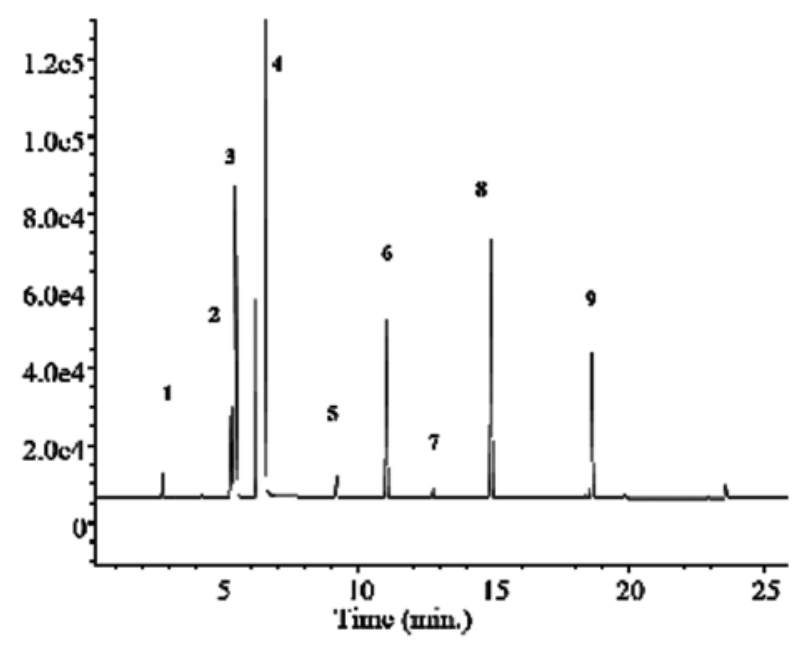

Fig. 1. Typical gas chromatogram of currant spirit distillate with direct injection: 1 , acetaldehyde;

$\mathbf{2}$, ethyl acetate; $\mathbf{3}$, methanol; $\mathbf{4}$, ethanol; $\mathbf{5}, \mathbf{1}$-propanol; 6, 2-methyl-1-propanol; 7, 1-butanol; 8, 2/3-methyl-1butanol; 9, 4-methyl-1-pentanol (internal standard)

Table 2

Chemical composition in currant brandies ( $\mathrm{g} / \mathrm{hl}$ A.A. unless otherwise indicated)

\begin{tabular}{|c|c|c|c|c|c|c|c|c|c|c|}
\hline & \multicolumn{2}{|c|}{ Rondom } & \multicolumn{2}{|c|}{ Versailles } & \multicolumn{2}{|c|}{ Ben Sarek } & \multicolumn{2}{|c|}{ Malling Juel } & \multicolumn{2}{|l|}{ Ometa } \\
\hline & Mean+SE & SD & Mean+SE & $\mathrm{SD}$ & Mean+SE & $\mathrm{SD}$ & Mean+SE & SD & Mean+SE & $\mathrm{SD}$ \\
\hline $\begin{array}{l}\text { Distillate I } \\
\text { (yield ml) }\end{array}$ & $753.3 \pm 14.5$ & 25.2 & $703.3 \pm 8.8$ & 15.3 & $1023.3 \pm 14.5$ & 25.2 & $1516.7 \pm 44.1$ & 76.4 & $616.7 \pm 16.7$ & 28.9 \\
\hline Ethanol \% vol & $15.7 \pm 0.3$ & 0.6 & $15.7 \pm 0.3$ & 0.6 & $18.7 \pm 0.4$ & 0.8 & $19.2 \pm 0.2$ & 0.3 & $18.5 \pm 0.3$ & 0.5 \\
\hline $\begin{array}{l}\text { Distillate II } \\
\text { (yield ml) }\end{array}$ & $163.3 \pm 3.3$ & 5.8 & $163.3 \pm 3.3$ & 5.8 & $330 \pm 5.8$ & 10 & $536.7 \pm 8.8$ & 15.3 & $210 \pm 5.8$ & 10 \\
\hline Ethanol \% vol & $42.7 \pm 0.3$ & 0.6 & $43.8 \pm 0.2$ & 0.3 & $44.5 \pm 0.2$ & 0.4 & $45.4 \pm 0.2$ & 0.4 & $45.1 \pm 0.1$ & 0.2 \\
\hline Acetaldehyde & $18.2 \pm 0.1$ & 0.1 & $8.7 \pm 0.03$ & 0.1 & $5.5 \pm 0.1$ & 0.2 & $43.4 \pm 1.0$ & 1.8 & $10.6 \pm 0.2$ & 0.4 \\
\hline Ethyl acetate & $113.1 \pm 0.2$ & 0.4 & $62.4 \pm 0.5$ & 0.8 & $16.9 \pm 0.1$ & 0.2 & $124.1 \pm 0.3$ & 0.6 & $63.9 \pm 0.5$ & 0.8 \\
\hline Methanol & $267.2 \pm 0.4$ & 0.7 & $345.2 \pm 1.9$ & 3.3 & $434.6 \pm 0.4$ & 0.6 & $595 \pm 1.4$ & 2.4 & $506.6 \pm 0.5$ & 1 \\
\hline 1-Propanol & $21.3 \pm 0.5$ & 0.9 & $18.7 \pm 0.9$ & 1.6 & $44.5 \pm 0.5$ & 0.8 & $34.4 \pm 1.1$ & 1.9 & $33.7 \pm 0.4$ & 0.7 \\
\hline $\begin{array}{l}\text { 2-Methyl- } \\
\text { 1-propanol }\end{array}$ & $63.7 \pm 0.7$ & 1.2 & $82.8 \pm 0.3$ & 0.5 & $129.6 \pm 1.6$ & 2.7 & $80.4 \pm 0.5$ & 0.8 & $61.7 \pm 0.4$ & 0.7 \\
\hline 1-Butanol & 0 & 0 & 0 & 0 & $2.3 \pm 0.1$ & 0.2 & $2.0 \pm 0.1$ & 0.2 & $1.5 \pm 0.1$ & 0.2 \\
\hline $\begin{array}{l}\text { 2/3 Methyl-1- } \\
\text { butanol }\end{array}$ & $74.2 \pm 0.5$ & 0.9 & $104.5 \pm 0.6$ & 1 & $165.3 \pm 0.5$ & 0.9 & $204.8 \pm 0.7$ & 1.2 & $187.1 \pm 33.6$ & 58.3 \\
\hline
\end{tabular}

Mean - arithmetic mean; SE(yEr \pm ) - Standard error; SD(yEr \pm ) - Standard deviation 
The obtained results were compared with those of other distilled alcoholic beverages such as plum [14], grape brandies, e.g. Portuguese Bagaceiras [13], Greek Tsipouro [15] and "Drenja" [16]. It was concluded that the composition of the analyzed samples was similar to the other tested samples.

Ta b le 3

Statistical significance of differences between data pairs, evaluated by one-way ANOVA followed by the Tukey test

\begin{tabular}{|c|c|c|c|c|c|}
\hline & Rondom & Versailles & Ben Sarek & Malling $J$ & Ometa \\
\hline \multicolumn{6}{|c|}{ Distillate I (yield ml) - Ethanol \% vol } \\
\hline Rondom & & n.s & $p<0.01$ & $p<0.01$ & $p<0.01$ \\
\hline Versailles & n.s & & $p<0.01$ & $p<0.01$ & $p<0.01$ \\
\hline Ben Sarek & $p<0.01$ & $p<0.01$ & & n.s & n.s \\
\hline Malling Juel & $p<0.01$ & $p<0.01$ & n.s & & n.s \\
\hline \multicolumn{6}{|c|}{ Distillate II (yield ml)-Ethanol \% vol } \\
\hline Rondom & & $p<0.01$ & $p<0.01$ & $p<0.01$ & $p<0.01$ \\
\hline Versailles & $p<0.01$ & & $p<0.01$ & $p<0.01$ & $p<0.01$ \\
\hline Ben Sarek & $p<0.01$ & $p<0.01$ & & $p<0.01$ & $p<0.05$ \\
\hline Malling Juel & $p<0.01$ & $p<0.01$ & $p<0.01$ & & n.s \\
\hline
\end{tabular}

n.s. $\rightarrow$ no statistical difference $(\mathrm{p}>0.05)$

At the 0.05 level of significance, the analysis of variance showed that the population means for alcohol were not significantly different between the analyzed samples Rondom Versailles, as well as between the analyzed samples Ben Sarek - Malling Juel and Ben Sarek - Ometa. The differences were not significantly different for the analyzed samples Malling Juel - Ometa (Table 3), which means that there was no difference observed in ethanol content, since the sugar content of the fruits was similar between the varieties.

The fermentation of fruit mashes relies on the conversion of fruit sugars to ethanol by yeast. The Embden-Meyerhof-Parnas Pathway (EMP) is the well-known process for the conversion of sugars to ethanol by yeast. This pathway proceeds by degrading sugar to acetaldehyde which is then reduced to ethanol. The yield of ethanol is dependent on the initial concentration of the total sugar present in the fruit, which is measured as total dissolved sugar present in the liquid mash. EC regulation 110/08 established the general manufacturing procedures of fruit spirits and fixed common analytical composition limits, i.e. $86 \%(V / V)$ of ethanol as the highest proof for the crude distillate and $37.5 \%$ $(V / V)$ as the minimal proof at bottling [12].

The results presented in Table 2 show that the cultivar Malling Juel produced the highest yields of both soft brandy $(1500 \mathrm{ml})$ and strong currant brandy $(540 \mathrm{ml})$, which was expected since it produced the highest dry matter and sugar content (Table 1) and it is well-known that the highest content of fermentable sugars are concentrated in dry matter structures. Considering the counter-correlation between dry matter and sugar/total acids, this proved best in the Malling Juel cultivar. The highest established sugar content in the cultivar Malling Juel led to the highest ethanol content in this distillate under identical conditions of distillation. 


\subsection{Methanol}

A low concentration of natural methanol exists in most alcoholic beverages and usually causes no immediate health threat [17]. Nevertheless, it is possible to have naturally occurring methanol in beverages at a concentration as high as $18 \mathrm{~g} / \mathrm{l}$ of ethanol, equivalent to $0.72 \%$ methanol in 40\% ethanol in alcohol [18]. Current EU regulations limit naturally occurring methanol to below $10 \mathrm{~g} / \mathrm{l}$ of ethanol, equivalent to $0.4 \%$ methanol in $40 \%$ ethanol [12].

Methanol found in alcoholic beverages is formed from the demethoxylation of esterified methoxyl groups in the pectin polymer and results from the hydrolysis of pectins by the enzyme pectin methyl esterase. The methanol content in the analyzed samples ranged between 267.2 and $595.0 \mathrm{~g} / \mathrm{hl} \mathrm{A}$. A. (maximum legal limit $1350 \mathrm{~g} /$ hl of $100 \%(V / V)$ ethanol), meaning that the manipulation of the raw material was fermented with great sensitivity and very good distillation procedures were performed. In comparison with other fruit mash distillates (apple, cherry, pear, and plum), the examined samples had a similar level of methanol. The highest methanol content in the distillate sample of the cultivar Malling Juel was explained by the highest content of dry matter (14.1\%, Table 1) which also includes pectin, the bearers of methoxy groups, which are the precursors of this alcohol.

\subsection{Acetaldehyde}

The tested spirits contained relatively small amounts of acetaldehyde, ranging from 5.5 to 43.4 $\mathrm{g} / \mathrm{hl}$ A.A. (Table 2). Other spirit beverages usually contain quite variable acetaldehyde levels, ranging from 153 to $1073 \mathrm{mg} / \mathrm{hl} \mathrm{A.A.} \mathrm{in} \mathrm{some} \mathrm{grape}$ brandies, e.g. Portuguese Bagaceiras and Greek Tsipouro (1330 mg/hl A.A.) [13, 20]. Europeanstyle spirits are defined by law; however, the regulation provides no limits for acetaldehyde for any of distilled spirits. Due to its unpleasant flavor, acetaldehyde is an undesirable substance in spirits. It is also regarded as "possibly carcinogenic to humans" [19]. During distillation, acetaldehyde is enriched in the first fraction, which is generally discarded. During the production of spirits, acetaldehyde may be formed not only as a product of alcoholic fermentation by Saccharomyces yeast, but also as a metabolite of microorganisms such as lactic acid or acetic acid bacteria. An increased amount of acetaldehyde usually indicates flaws in the fermentation process.

\subsection{Ethyl acetate}

Esters are very important compounds due to their particular contribution to flavor and aroma, since they have the lowest organoleptic threshold values [20]. The quantity of this compound present in the final product can vary widely, since it is synthesized from acetic acid (in form of acetylCoA) and ethanol [21]. The mean values of the concentration of ethyl acetate for studied samples ranged from 16.9 to 124.1 (Rondom $113.1 \pm 0.2 \mathrm{~g}$ / hl A.A., Versailles $62.4 \pm 0.5 \mathrm{~g} / \mathrm{hl}$ A.A., Ben Sarek $16.9 \pm 0.1 \mathrm{~g} / \mathrm{hl}$ A.A., Malling Juel $124.1 \pm 0.3 \mathrm{~g} / \mathrm{hl}$ A.A. and Ometa $63.9 \pm 0.5 \mathrm{~g} / \mathrm{hl}$ A.A.).

High concentrations of ethyl acetate are indicative of prolonged storage of the raw material and probable acetic bacterial spoilage. Concerning ethyl acetate, many authors have documented high variability. It was generally found at lower levels than the usual values for tsipuro [15], meszcal [22], bagaceira [13], and orujo [23]. Filajdić and Djuković found a very high ethyl acetate content (4648 mg/hl A.A.) in home-made plum brandies [24]. Comparing these results, it can be concluded that the concentrations of ethyl acetate found in these samples are commonly acceptable.

\subsection{Higher alcohols}

The most important higher alcohols of currant distillates (Table 2) are amyl alcohols (2-methyl-1-butanol and 3-methyl-1-butanol), 2-methyl-1-propanol, and 1-propanol. In the analyzed samples, the content of amyl alcohols ranged from 74.2 to $204.8 \mathrm{~g} / \mathrm{hl}$ A.A. For these two compounds, Silva et al. [13] gave for Portuguese 
bagaceiras concentrations similar to ours, ranging from 62.2 to $204.4 \mathrm{~g} / \mathrm{hl} \mathrm{A.A.} \mathrm{Soufleros} \mathrm{[25]}$ presented concentrations ranging from 120.9 to $210.7 \mathrm{~g} / \mathrm{hl} \mathrm{A}$.A. for the traditional Greek fruit distillate "Mouro". According to Tešević et al. [16], the concentrations of amyl alcohols in the "Drenja" distillate obtained from cornelian cherry ranges from 148.9 to $263.5 \mathrm{~g} / \mathrm{hl}$ A.A., which is higher than levels in currant spirits.

The level of 2-methyl-1-propanol, the second most abundant compound in Currant brandy samples, ranged between 61.7 to $129.6 \mathrm{~g} / \mathrm{hl} \mathrm{A.A.}$ Silva et al. [26] reported that 2-methyl-1-propanol contributes favorable notes to distilled beverages. Tešević et al. [25] reported for "Drenja" mean values equal to 45.8 to $144.9 \mathrm{~g} / \mathrm{hl} \mathrm{A}$.A. for 2-methyl-1-propanol. Also, for bagaceiras, Silva and Malcata [13], depending on the grape variety, demonstrated mean values for 2-methyl-1-propanol from 77.1 to $85.1 \mathrm{~g} / \mathrm{hl}$ A.A. The 1-propanol level of the studied samples was in the range of 18.7 to $21.3 \mathrm{~g} / \mathrm{hl} \mathrm{A}$.A. for black currant spirits and 33.7 to $44.5 \mathrm{~g} / \mathrm{hl}$ A.A. for red currant spirits. The compound has a pleasant, sweetish odor with a threshold value of $0.57-4.0 \mathrm{~g} / \mathrm{hl}$, but excessive levels can lead to solvent-like negative notes in distillates [27]. In comparison, Tešević et al. [16], for 1-propanol, presented concentrations of 13.2 to $30.0 \mathrm{~g} / \mathrm{hl}$ A.A. for distillates coming from cornelian cherry. Silva et al. [13], for bagaceiras reported, that 1-propanol varies from 14.2 to 37.7 g/hl A.A.

The maximum and the minimum of total higher alcohols (2-butanol, isobutanol, 1-butanol, 1-propanol, and isoamyl alcohols) are fixed by the Regulating Commission at 225 and $600 \mathrm{~g} / 1001$ of pure alcohol, respectively. Both groups of spirits were within these limits.

\subsection{Sensory evaluation}

Since distilled beverages are a very complex matrix, the quality cannot be accurately predicted by analytical analyses alone. Sensory tests are necessary in order to complement the analytical results to determine the best quality drink.

Table 4 shows the sensory scores. All samples scored 1.0 point for color, 1.0 point for clearness and 2.0 points for distinction; odor had the highest score of 5.5 in spirits produced from the Ben Sarek and Maliing Juel cultivars. The highest scores for taste were obtained in spirits produced from the Ometa cultivar (9.0). The highest total score of 18.4 points was recorded for the spirit produced from the Ben Sarek cultivar followed by Ometa (18.30) and Malling Juel (18.20). The distillates obtained from the cultivars Malling Juel and Ben Sarek had the highest higher alcohol content (321.6 g/hl A.A. and (341.7 g/ hl A.A., respectively), which along with esters, terpenic alcohols, and some lactones [5] present the key components of odor and aroma of all fruit distillates. Furthermore, the presence of 1-propanol stands out in these distillates. It has a very pleasing, intriguing and refreshing odor that certainly contributed to the high sensory scores of these distillates.

Table 4

Sensory analyses of the currant brandies

\begin{tabular}{|c|c|c|c|c|c|c|}
\hline \multirow{2}{*}{$\begin{array}{l}\text { Brandies } \\
\text { samples }\end{array}$} & \multicolumn{6}{|c|}{ Assessment characteristics } \\
\hline & $\begin{array}{c}\text { Color } \\
\text { (max } 1 \text { pts) }\end{array}$ & $\begin{array}{l}\text { Clearness } \\
\text { (max 1 pts) }\end{array}$ & $\begin{array}{l}\text { Distinction } \\
\text { (max } 2 \text { pts) }\end{array}$ & $\begin{array}{c}\text { Odor } \\
(\max 6 \text { pts) }\end{array}$ & $\begin{array}{c}\text { Taste } \\
(\max .10 \mathrm{pts})\end{array}$ & $\begin{array}{c}\text { Total } \\
(\max 20 \mathrm{pts})\end{array}$ \\
\hline Ben Sarek & 1 & 1 & 2 & 5.50 & 8.90 & 18.40 \\
\hline Malling Juel & 1 & 1 & 2 & 5.50 & 8.70 & 18.20 \\
\hline Rondom & 1 & 1 & 2 & 5.40 & 8.40 & 17.80 \\
\hline Ometa & 1 & 1 & 2 & 5.30 & 9.00 & 18.30 \\
\hline Versailles & 1 & 1 & 2 & 5.20 & 8.40 & 17.60 \\
\hline
\end{tabular}




\section{CONCLUSIONS}

The findings presented in this paper provide a picture of the major volatile compounds in distillates produced from three black currant cultivars and two red currant cultivars. This study demonstrated for the first time that currant berries can be used to produce high quality alcoholic beverages.

In general, the compounds identified in major quantities in currant spirits are similar to those present in other alcoholic beverages. In currant distillates, the major volatile compounds that pose health hazards or organoleptic faults such as methanol, acetaldehyde, ethyl acetate, and high alcohols were found at levels lower than those established by the EC. Currant spirits produced from five currant cultivars were similar in their content of certain volatile components, which influence their quality and sensory characteristics. All currant spirits whose characteristics were analyzed for sensory characteristics were highly graded. Maintaining the high quality of the product while scaling up the process would require better standardization and quality control, as well as a more systematic approach to the production procedure.

Acknowledgements. The authors acknowledge the financial support of the Serbian Ministry of Science and Technological Development (Project No. 172053).

\section{REFERENCES}

[1] M. Rieger, The Mark's Fruit Crops. http://www. uga.edu/fruit/ribes.html [accessed August 2006].

[2] C. Varming, M. L. Andersen, L. Poll, Influence of thermal treatment on black currant (Ribes nigrum L.) juice aroma, J. Agric. Food Chem., 52, 76287636 (2004).

[3] A. Chevallier, The Encyclopedia of Medicinal Plants; Emerson-Roberts, G., Ed.; Dorling Kindersley Ltd.: London, U.K., 1996.

[4] L. M. Nijssen, C. A. Visscher, H. Maarse, L. C. Willemsens, M. H. Boelsens (eds), Volatile compounds in food: qualitative and quantitative data. 7th edn. TNO Nutrition and Food Research Institute, Zeist., 1996.

[5] A. Latrasse, J. Rigaud, J. Sarris, Aroma of the blackcurrant berry (Ribes nigrum L.). Main odour and secondary notes, Sci. Aliments, 2, 145-162 (1982).

[6] A. C. Rice-Evans, N. J. Miller, G. Paganga, Structure-antioxidant activity relationships of flavonoids and phenolic acids, Free Radical Biology \& Medicine, 20, 33-956 (1996).

[7] I. M. Heinonen, P. J. Lehtonen, A. I. Hopia. Antioxidant activity of berry and fruit wines and liquors, J. Agric Food Chem. 46, 25-31 (1998).

[8] K. A. Berglund, Artisan Distilling. A Guide for Small Distilleries, http://www.distilleryyeast.com/ ARTISANDISTILLING1.0.0.pdf, Electronic Edition 1.0.0, March 25, 2004.

[9] S. Gorjanović, M. M. Novaković, P. V. Vukosavljević, F. T. Pastor, V. V. Tešević, D. Sužnjević, Polarographic Assay Based on Hydrogen Peroxide Scavenging in Determination of Antioxidant Activity of Strong Alcohol Beverages, J. Agric. Food Chem., 58, 8400-8406 (2010).

[10] Plutowska, W. Wardencki, Application of gas chromatography-olfactometry (GC-O) in analysis and quality assessment of alcoholic beverages, Food Chem., 107, 449-463 (2008).

[11] A.O.A.C. Official methods of analysis, 16th Ed. Association of Official Analytical Chemists, Inc. U.S.A. 1995.

[12] EEC, Council Regulation No. 110/2008 of 15 January 2008, Laying down general rules on the definition, description and presentation of spirit drinks. Off. J. Eur. Union, L 39/16, 17-18 (2008).

[13] M. L. Silva, F. X. Malcata, G. de Revel, Volatile contents of grape marcs in Portugal, J. Food Compos. Anal., 9, 72-80 (1996).

[14] V. Tešević, N. Nikićević, A. Jovanović, D. Djoković, Lj. Vujisić, I. Vučković, "Volatile components from old plum brandies", Food Technol. Biotechnol., 43, 367-372 (2005).

[15] A. A. Apostolopoulou, A. I. Flouros, P. G. Demertzis, K. Akrida-Demertzi, Differences in concentration of principal volatile constituents in traditional Greek distillates, Food Cont., 16, 157-164 (2005).

[16] V. Tešević, N. Nikičević, S. Milosavljević, D. Bajić, V. Vajs, I. Vučković, Lj.Vujisić, I. Đordević, M. Stanković, M. Veličković, Characterization of volatile compounds of 'Drenja', an alcoholic bev- 
erage obtained from the fruits of cornelian cherry, J. Serb. Chem. Soc., 74, 117-128 (2009).

[17] A. J. Paine, A. D. Dayan, Defining a tolerable concentration of methanol in alcoholic drinks, Hum. Exp. Toxicol., 20, 563-568 (2001).

[18] F. Bindler, E. Voges, P. Laugel, The problem of methanol concentration admissible in distilled fruit spirits, Food Addit. Contam., 5, 343-351 (1988).

[19] D. W. Lachenmeier, E. M. Sohnius, The role of acetaldehyde outside ethanol metabolism in the carcinogenicity of alcoholic beverages: Evidence from a large chemical survey, Food Chem.Toxicol., 46, 2903-2911 (2008).

[20] C. M. Ramsay, D. R. Berry, The effect of temperature and $\mathrm{pH}$ on the formation of higher alcohols, fatty acids and esters in malt whisky fermentation, Food Microbiol., 1, 117-125 (1984).

[21] M. L. Silva, A. C. Macedo, F. X. Malcata, Steam distilled spirits from fermented grape pomace, Food Sci. Technol. Int., 6, 285-300 (2000).

[22] De Leon-Rodriguez, L. Gonzalez-Hernandez, A. P. Barba de la Rosa, P. Escalante-Minakata, M. G. Lopez, Characterization of volatile compounds of Mezcal, an ethnic alcoholic beverage obtained from Agave salmiana, J. Agric. Food Chem., 54, 1337-1341 (2006).

[23] S. Cortés, M.L. Gil, E. Fernández, Volatile composition of traditional and industrial Orujo spirits, Food Cont., 16, 383-388 (2005).

[24] M. Filajdić, J. Djuković, Gas-chromatographic determination of volatile constituents in Yugoslav plum brandies, J. Sci. Food Agric., 24, 835-842 (1973).

[25] E. H. Soufleros, A. S. Mygdalia, P. Natskoulis, Characterization and safety evaluation of the traditional Greek fruit distillate Mouro by flavor compounds and mineral analysis, Food Chem., 86, 625-636 (2004).

[26] M. L. Silva, F. X. Malcata, Effects of time of grape pomace fermentation and distillation cuts on the chemical composition of grape marcs, Z. Lebensm. Unters. Forsch. A, 208, 134-143 (1999).

[27] M. Fundira, M. Blom, I. S. Pretorius, P. van Rensburg, Selection of yeast starter culture strains for the production of marula fruit wines and disitlate, J. Agric. Food Chem., 50, 1535-1542 (2002). 
